\title{
Short Communication: \\ Identification and characterization of nitrifying bacteria in mud crab (Scylla serrata) recirculation aquaculture system by 16S rRNA sequencing
}

\author{
YUNI PUJI HASTUTI ${ }^{1, \bullet}$, IMAN RUSMANA ${ }^{2}$, KUKUH NIRMALA ${ }^{\mathbf{1}}$, RIDWAN AFFANDI ${ }^{3}$, SISKA TRIDESIANTI \\ ${ }^{1}$ Department of Aquaculture, Faculty of Fisheries and Marine Science, Institut Pertanian Bogor. Jl. Raya Dramaga, Bogor 16680, West Java, Indonesia. \\ Tel.: : +62 2518622909 -8622911, Fax.: +62 251 8622907, ‘email: yuni_ph2@yahoo.com; yuniha@ipb.ac.id \\ ${ }^{2}$ Department of Biology, Faculty of Mathematics and Natural Sciences, Institut Pertanian Bogor. Jl. Raya Dramaga, Bogor 16680, West Java, Indonesia \\ ${ }^{3}$ Department of Management of Water Resources, Faculty of Fisheries and Marine Science, Institut Pertanian Bogor. Jl. Raya Dramaga, Bogor 16680, \\ West Java, Indonesia
}

Manuscript received: 17 September 2018. Revision accepted: 25 April 2019.

\begin{abstract}
Hastuti YP, Rusmana I, Nirmala K, Affandi R, Tridesianti S. 2019. Identification and characterization of nitrifying bacteria in mud crab (Scylla serrata) recirculation aquaculture system by 16S rRNA sequencing. Biodiversitas 20: 1339-1343. Recirculation is one of the systems used for increasing aquaculture production, for example, is mud crab Scylla serrata culture. Aquaculture activities will produce organic nitrogen waste and can be affected to inorganic condition (nitrification bacteria). Nitrifying bacteria are capable of changing aerobically from $\mathrm{NH}_{4}{ }^{+}$to $\mathrm{NO}_{2}^{-}$(nitrite) and from $\mathrm{NO}_{2}{ }^{-}$to $\mathrm{NO}_{3}{ }^{-}$(nitrate). This current work aimed to identify and characterize nitrifying bacteria in mud crab (S. serrata) culture with a recirculated system. Nitrifying bacteria were isolated using serial dilution $\left(10^{-1}\right.$ until $10^{-5}$ ) of open filter FB water sample previously cultured in a specific medium. Bacterial identification was performed using a procedure of Presto ${ }^{\mathrm{TM}}$ Mini gDNA Kit (Geneid) for DNA extraction and Polymerase Chain Reaction (PCR) primer 63F and 1387R for 16S rRNA gene amplification. Molecular identification using 16S rRNA sequences, the nitrifying bacteria isolated from mud crab recirculation aquaculture system were $99 \%$ identified as a group Pantoea calida, Pseudomonas stutzerii dan Halomonas sp. Morphological characterization of the colony morphology showed that a mucoid appearance and appeared cream in color and large size. Furthermore, their cells were recognized as basil and Gram-negative.
\end{abstract}

Keywords: Bacteria, characterization, identification, nitrification, Scylla serrata

\section{INTRODUCTION}

Mud crab (Scylla serrata) is recognized as one of the exotic crustaceans and acquires economic importance with increasing demand, but its production shows a decrease. From 2000 to 2010, production of mud crab increased up to $183.5 \%$, which its live distribution reaches $2.1 \%$ (Food and Agriculture Organization-FAO 2011). On the contrary, the technology of mud crab culture was rather scarce, which was unable to meet its high demand (FAO 2016). Recirculation Aquaculture System (RAS) was proposed to increase the mud crab production. RAS was applicable to maintain culture condition and to deal with water limitation (Metaxa et al. 2006). Presence of integrated recirculation in RAS could promote reduction-oxidation reaction of toxic compounds, which provided an answer to increase crab production.

Waste of environmental aquaculture is a source of Dissolved Organic Nitrogen (DIN) is used by microorganisms to produce DIN products. Bacteria degrading organic materials would produce $\mathrm{NH}_{4}{ }^{+}$, which is, in turn, transform into $\mathrm{NH}_{3}$. Nitrifying bacteria enabled to produce $\mathrm{NO}_{2}^{-}$(nitrite) from $\mathrm{NH}_{4}{ }^{+}$and $\mathrm{NO}_{3}^{-}$(nitrate) from $\mathrm{NO}_{2}$-under aerobic condition. This suggested that the bacteria could improve nitrification and denitrification of nitrogen available in shrimp culture (Hastuti, 2011). Camargo and Alonso (2006) found that toxicity of inorganic nitrogen compounds including ammonia $\left(\mathrm{NH}_{3}\right)$, nitrite $\left(\mathrm{NO}_{2}^{-}\right)$, and nitrate $\left(\mathrm{NO}_{3}{ }^{-}\right)$at a particular concentration could promote mortality for aquatic animals. In addition, these compounds also adversely affected their physiological, neurological, and cytological functions, thereby inducing stress condition and less feed consumption (Constable et al. 2003).

Identification of nitrifying bacteria is critical for the process of cultivation environment aquaculture, one of the approaches is by using molecular technique. The identification of particular nitrification bacteria for mud crab environment culture is considered as an initial stage for the analysis of nitrifier diversity in a controlled environmental.

The presence of nitrifying bacteria in aquaculture environments can balance the ecosystem of aquaculture by degrading ammonia waste from ammonification of organic feed waste and metabolic waste. The nitrifying bacteria can degrade ammonia into nitrite and subsequently to become nitrate with the assistance of ammonia oxidase (Amoa) and nitrite bioxidase (NoB) enzyme. The nitrifying bacteria can be identified using DNA sequence of $16 \mathrm{~S}$ rDNA (Stackebrandt et al. 1991). 
During culture, the concentration of ammonia, nitrite, and nitrate was increased with the increasing age of mud crab, which affected its survival (Hastuti et al. 2015). The concentration of nitrite in day 45 reached $1.02 \mathrm{mg} \mathrm{L}^{-1}$ and continuously increased up to $1.72 \pm 0,57 \mathrm{mg} \mathrm{L}^{-1}$ in day 100 . In the case of vannamei culture, a remarkable increase of nitrite and ammonium-producing bacteria was recorded up to $7.03 \log \mathrm{CFU} \mathrm{L}^{-1}$ in day 30 (Hastuti et al. 2010). In the aerobic system, ammonium removal could be performed by oxidizing ammonium $\left(\mathrm{NH}_{4}^{+}\right)$through enhanced nitrification activities induced by nitrite-forming bacteria (ammonium oxidizer) and nitrate-forming bacteria (nitrite oxidizer). Nitrite $\left(\mathrm{NO}_{2}{ }^{-}\right)$served as electron acceptor with the presence of denitrifying bacteria under an anaerobic system, which was then reduced into $\mathrm{N}_{2} \mathrm{O}$ and $\mathrm{N}_{2}$ gas (Zumft 1997; Richardson 2000). Nitrification allows reduction of harmful compounds (ammonia and nitrite) into inorganic nitrogen compound (nitrate) that are not toxic. Therefore, this current work aimed to identify and characterize nitrifying bacteria present in mud crab recirculation aquaculture system.

\section{MATERIALS AND METHODS}

Samples were taken from the environmental recirculation of mud crab (Scylla serrata) culture. Mud crab (S. serrata) as test biota was sampled from the coast of Banjarmasin in South Kalimantan and Pasuruan in East Java, and reared in Laboratory of Environmental, Department of Aquaculture, Faculty of Fisheries and Marine Science, Bogor Agricultural University (IPB), Bogor, Indonesia. Bacteria were isolated and characterized in Laboratory of Microbiology, Department of Biology, Faculty of Mathematics and Natural Sciences, IPB. Seawater used in this study was taken from Ancol beach, Jakarta, Indonesia.

\section{Installation of mud crab RAS}

Mud crab (10 individuals) was parallelly reared in a culture tank containing $60 \mathrm{~L}$ of seawater. Recirculation system was made by using six shelters (total area of 220 $\mathrm{cm}^{2}$ ) at a density of 10 crabs, using seawater with a salinity of $25 \mathrm{~g} \mathrm{~L}^{-1}$ (obtained by dilution) oxygen level of $>5 \mathrm{mg} \mathrm{L}^{-1}$ in culture tank, the temperature of $27-31^{\circ} \mathrm{C}$, and $\mathrm{pH}$ of 6.5 7.5. For each treatment, two filter chambers contained (Hastuti et al. 2017). Close Filter System (operated as an anaerobic filter) and an Open Filter System (as aerobic filter) were installed with the capacity of $220 \mathrm{~L}$ per chamber (water debit of $0.125 \mathrm{~L} \mathrm{sec}^{-1}$, water pump capacity of $200 \mathrm{~V}$ ) (Figure 1). Water sample for specific nitrification bacteria was taken from the open filter system or aerobic condition filter. Each filter system was equipped with inlet and outlet. Practically, water from the culture tank was flowed into anaerobic filter chamber (consisting of 250 bio balls, $40 \mathrm{~kg}$ zeolite, $90 \mathrm{~kg}$ grains of sand, 800-1200 bio balls, respectively from bottom to top, and covered by gauze), while waved fiber was set in aerobic filter chamber. For bacterial isolation, water was sampled from the inlet of the aerobic filter.

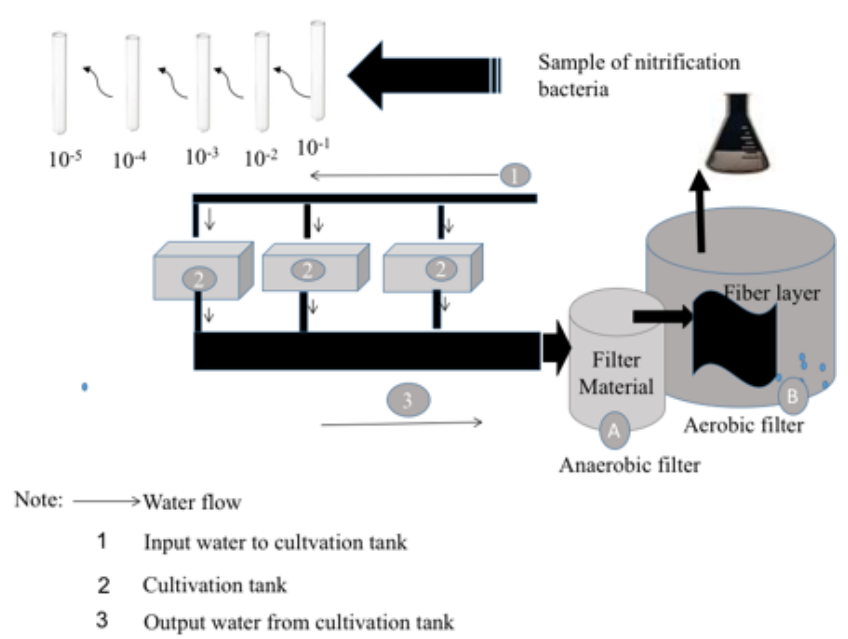

Figure 1. Installation of Recirculated Aquaculture System for mud crab culture and sample collection

\section{Isolation of nitrifying bacteria from mud crab RAS}

The water sample was diluted at $10^{-1}, 10^{-2}, 10^{-3}, 10^{-4}$, and $10^{-5}$. The bacteria were isolated in heterotroph specific media containing succinate as carbon source and ammonium as a single source of nitrogen and incubated for five days (White 2000). The composition of nitrifying bacteria medium consisted of $\mathrm{KH}_{2} \mathrm{PO}_{4}, \mathrm{Na}_{2} \mathrm{HPO}_{4}, \mathrm{FeCl}_{3}$, $\mathrm{CaCl}_{2}$ and yeast extract. The resulting pure isolate was observed for colony morphology (form, color, margin, and size). Gram staining was used to distinguish bacterial species (Hadioetomo 1983).

\section{DNA extraction, amplification, and identification of the 16S rRNA genes in the isolated cells}

The DNA of selected pure isolates was extracted using the protocol of Presto ${ }^{\mathrm{TM}}$ Mini gDNA Kit (Geneid). The concentration and purity of extracted DNA were then determined using Nanodrop 2000 (Thermo Scientific, Wilmington DE, USA). Genomic DNA from the extraction of nitrification bacteria in aquaculture system was used for PCR amplification of the 16S rRNA primer pair 63F (5'CAG GCC TAA CAC ATG CAA GTC-3') and 1387R (5'GGG CGG WGT GTA CAA GGC-3') (Marchesi et al. 1998). The final concentration of each reagent PCR reaction was $25 \mu \mathrm{L}$, consisting of $12.5 \mu \mathrm{L}$ from GoTag Green Master Mix 2X (Promega, Madison, W1, USA) or Red mix my tag (Bioline), $2.5 \mu \mathrm{L}$ primer $63 \mathrm{~F}$ and $1387 \mathrm{R}$ (concentration of $10 \mathrm{pmol}$ ); $6.5 \mu \mathrm{L}$ Nuclease-Free Water, and $1 \mu \mathrm{L}$ genomic DNA templates. PCR experiment consisted of 35 cycles and was performed by following conditions: pre-denaturation $\left(95{ }^{\circ} \mathrm{C} ; 5 \mathrm{~min}\right)$, denaturation $\left(95{ }^{\circ} \mathrm{C} ; 15 \mathrm{~min}\right)$, annealing $\left(55^{\circ} \mathrm{C} ; 1 \mathrm{~min}\right)$, elongation $(72$ $\left.{ }^{\circ} \mathrm{C} ; 1.5 \mathrm{~min}\right)$, and extension $\left(72^{\circ} \mathrm{C} ; 10 \mathrm{~min}\right)$. The DNA sequences of $16 \mathrm{~S}$ rRNA were subjected to BLAST-N in NCBI website (blast.ncbi.nlm.nih.gov) to search for the homologous sequence alignment. A phylogenetic tree was constructed using Mega 6.00 Neighbour Joining Boostrap 
2000x replicates (Tamura et al. 2013). The alignment process of the results is made phylogenetic tree construction by method of Neighbor-Joining. Diversity and uniformity of indexes are estimated based on interpretations that were carried out by CLIQS ID software and processed with Past3 software.

\section{RESULTS AND DISCUSSION}

\section{Isolation of nitrifying bacteria}

Selection of nitrifying bacteria was performed through the following steps: purification, biochemical test for nitrifying bacteria, OF test, and metabolic activity test (Table 1). From 169 initial isolates of nitrifying bacteria, 68 isolates were obtained through further selection based on their stability and growth rate. All of 68 isolates were observed for their capability in oxidizing $\mathrm{NH}_{4}{ }^{+}, \mathrm{NO}_{2}{ }^{-}$and ultimately forming $\mathrm{NO}_{3}{ }^{-}$. According to bacterial metabolic activity, 20 isolates were obtained, and a further test was carried out including biochemical test and quantitative analysis. Partial performance of nitrification bacteria has been produced with a relatively higher source of ammonium (Dong et al. 2017). The results of abundance nitrifying bacteria from different container showed a significant difference (Hastuti et al. 2018).

Based on the morphological examination of five isolates of nitrifying bacteria, it showed that most isolates were classified as Gram-negative (Table 2). Previous studies reported that strains of nitrifying bacteria with heterotrophic and aerobic denitrification activity were from Paracoccus sp., Bacillus licheniformis and Pseudomonas stutzeri (Takenaka et al. 2007; Miyahara et al. 2010). Also, Zhang et al. (2011) reported that YZN001 strain with nitrification activity has features such as rod-shaped, Gram-negative, motile, catalase-positive and oxidase-positive. Identification of nitrifying bacteria in the RAS culture of mud crabs has been identified in some ways which have motility, catalase and oxidase capabilities. From the colors that are produced, there is a color of the bacteria that appears that is yellow, white and a tone that has large colonies and there are small colonies.

Pseudomonas putida strain Y-9 is known to be a heterotrophic bacterium that has nitrification activity in wastewater management (Xu et al. 2016). Pseudomonas putida as heterotrophic nitrifying bacteria including as mesophilic and is capable of low-temperature activity. Even pseudomonas putoda Y-9 is capable of active denitrification at low temperatures. With the identification of nitrifying bacteria in a culture environment, it can be interpreted that there is a group of bacteria capable of degrading ammonium in high quantities. The treatment of dark containers has a significant effect on growth of mud crabs so that this study can provide important information in the development of mud crab cultivation technology (Hastuti et al. 2018) and based on the results, S. serrata culture using light container at high light intensity demonstrated the better result in comparison with using dark container.

Several environmental factors such as substrate concentration, temperature, $\mathrm{pH}$, salinity, dissolved oxygen (DO), $\mathrm{C} / \mathrm{N}$ ratio and organic carbon (C) availability strongly influenced the growth of nitrifying bacteria and nitrification activity in these bacteria. Reported by Isnansetyo et al. (2014) that nitrifying bacteria (NR code) from Ariake seawater can grow a temperature between $15^{\circ}$ $\mathrm{C}$ to $29.5^{\circ} \mathrm{C}$ Kim et al. (2008) reported a similar finding in that nitrification activity is constant value at a temperature range $10-30^{\circ} \mathrm{C}$, while in this study, the $\mathrm{pH}$ of the FB filter during maintenance is $5.68-7.98$.

Table 1 Isolation of nitrifying bacteria from mud crab recirculation aquaculture system

\begin{tabular}{ccccc}
\hline Type of bacteria & $\begin{array}{c}\text { The initial number } \\
\text { of isolate }\end{array}$ & Well growth isolate & $\begin{array}{c}\text { Isolates by their metabolic } \\
\text { activity }\end{array}$ & The selected isolates \\
\hline Nitrifying bacteria & 169 & 68 & 20 & 3 \\
\hline
\end{tabular}

Table 2 Morphological characteristics of the ammonium oxidation bacteria (AOB) colony and cell in mud crab recirculation aquaculture system

\begin{tabular}{lllccc}
\hline Isolate code & Colony morphology & Cell morphology & Motility & Catalase & Oxidase \\
\hline HIB_b & Large, yellowish, slimy colony & Rod/Gram- & + & + & + \\
HIB_d & A small, pale yellowish white colony & Rod/Gram- & + & + & + \\
HIB_e & Large, yellowish, slimy colony & Rod/Gram- & + & + & + \\
HIB_f & Large, yellowish, slimy colony & Rod/Gram- & - & + & + \\
HIB_g & Small, clear transparent, slimy colony & Rod/Gram- & + & + & + \\
\hline
\end{tabular}

Note: HIB: Indigenous bacteria with isolate code of $b, d, e, f$ and $g$ 


\section{Molecular identification of nitrifying bacteria isolates}

The DNA purity of the nitrifying bacteria was relatively high, with A260/280 of 1.83-2.36 and A260/230 of 1.092.27. The purity from each isolate was high, ranging from $1.94 \pm 0.01$ to $2.34 \pm 0.02$ (Table 3 ) A260 shows the values of DNA and A230 for phenol and humic acid, A280 value is the wavelength for protein. The A260 / 230 is considered good if the value more than 2.0, indicating that no humic acid-like molecules are detected in A230 wavelength absorption. Humic acid is a type of contaminant which enables to adversely affect the quantification of DNA since it is detected at A230 nm and A260 nm (Yeates et al. 1998), The RAS environment culture can produce a good nitrifying bacterial community for ammonia waste degradation. Ammonia can be degraded by a group of nitrifying bacteria into nitrite and then becomes nitrate.

Results from BLAST-N search showed that the DNA sequences of both nitrifying bacteria from this study and those from the NCBI database have similarity value of $99 \%$ and $100 \%$. The phylogenetic tree of nitrification bacteria showed that HIB_b, HIB_e, and HIB_g was amplified as a group Pantoea calida, Pantoea sp, while HIB_d was recognized as Pseudomonas stutzeri, and HIB_f was recorded as Halomonas sp, Salinicola salaries (Figure 2).

Table 3. The quantification of nitrification isolates in the mud crab (Scylla serrata) with recirculation system

\begin{tabular}{llll}
\hline Isolate Code & $\begin{array}{l}\text { Concentration } \\
\text { DNA }\left(\mathbf{n g} \boldsymbol{\mu} \mathbf{L}^{-1}\right)\end{array}$ & $\mathbf{A 2 6 0 / 2 8 0}$ & $\mathbf{A 2 6 0 / 2 3 0}$ \\
\hline HIB_b & $162.35 \pm 3.25$ & $1.90 \pm 1.34$ & $2.05 \pm 0.02$ \\
HIB_d & $53.15 \pm 0.15$ & $1.94 \pm 0.01$ & $2.03 \pm 0.01$ \\
HIB_e & $133.50 \pm 1.00$ & $1.94 \pm 0.01$ & $2.25 \pm 0.01$ \\
HIB_f & $168.35 \pm 1.45$ & $1.99 \pm 0.01$ & $2.26 \pm 0.01$ \\
HIB_g & $16.25 \pm 0.25$ & $2.34 \pm 0.02$ & $1.10 \pm 0.01$ \\
\hline
\end{tabular}

Note: HIB: Indigenous bacteria with isolate code of $b, \mathrm{~d}, \mathrm{e}, \mathrm{f}$ and $\mathrm{g}$

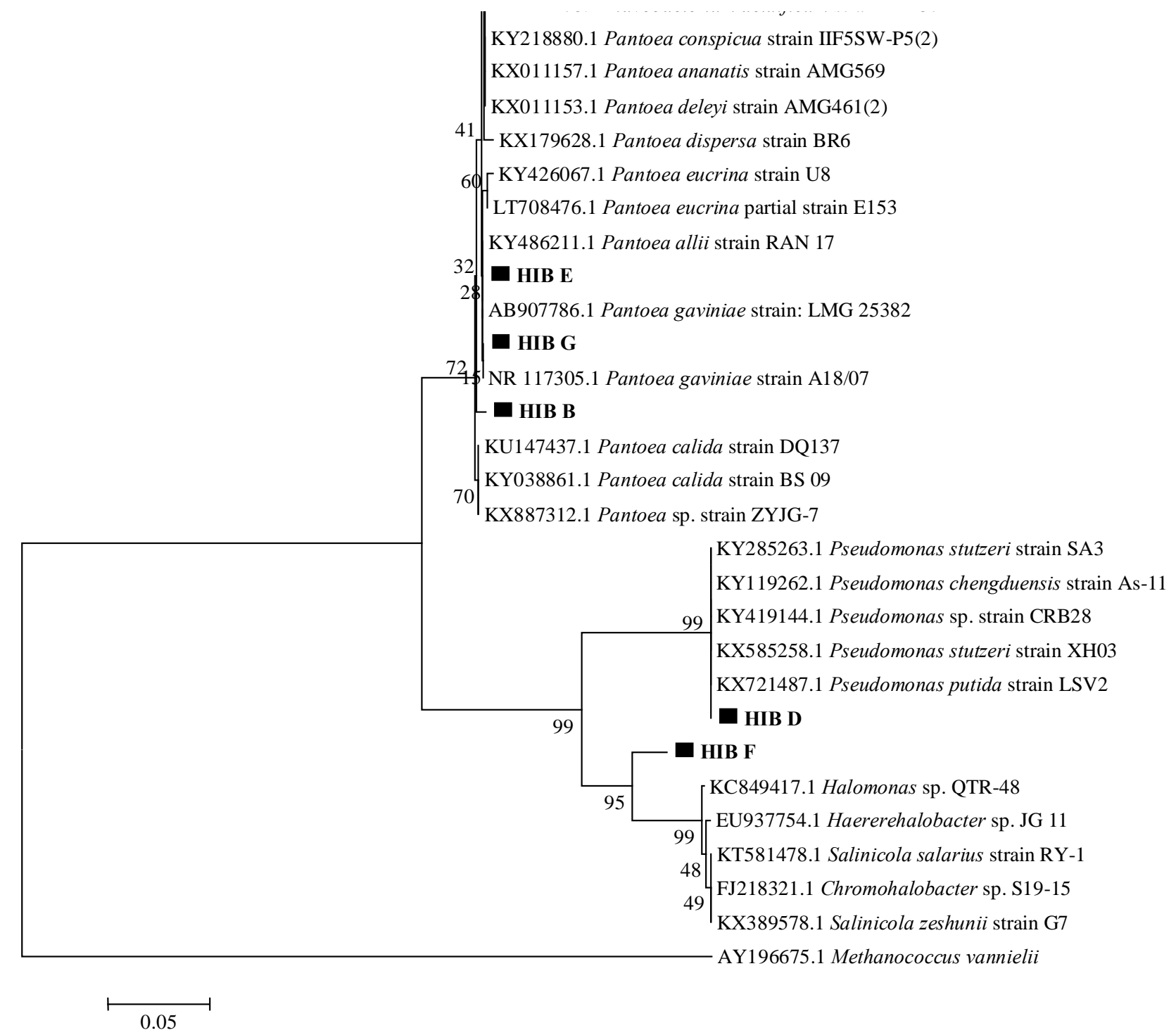

Figure 2 Phylogenetic tree of nitrification bacteria isolated from mud crab (Scylla serrata) recirculation aquaculture system. Tamura-3 parameters, 2000× Bootstrap replicates using Mega 6.00 Neighbour Joining Boostrap 2000× replicates (Tamura et al. 2013). 
Halomonas spp. is potential nitrifying bacteria for saline ammonium wastewater (Sangnoi et al. 2017). Pseudomonas can grow well at high ammonium concentrations in Jogjakarta farms (Fitriyanto et al. 2017). Ammonium is used by the bacteria Pseudomonas to become nitrite and then nitrate. All nitrifying bacteria that have the character of couple nitrification-denitrification can oxidize ammonium and reduce nitrate. Microbial communities can be applied for the management of biological, industrial waste, including the archaea group (Calderon et al. 2013). In addition to its role in the process of nitrifying, Thauera, Pseudomonas, and Denitromonas also have a function as denitrification microbes, which are commonly used in activated sludge and form biofilms in the marine environment (Gao et al. 2012; Babatsouli et al. 2015; Wang et al. 2017). Halomonas campisalis is a halophilic strain has the ability as heterotrophic nitrification and aerobic denitrification bacteria that can remove inorganic nitrogen compounds (e.g., $\mathrm{NH}_{4}^{+}, \mathrm{NO}_{2}^{-}$ and $\left.\mathrm{NO}_{3}{ }^{-}\right)$and related the enzyme napA, nirS, norB and nosZ (Guo et al. 2013).

In conclusion, based on an identification of $16 \mathrm{~S}$ rRNA genes, nitrifying bacteria isolated from mud crab recirculation aquaculture system showed a similarity of 99 $\%$ to Pantoea calida, Pseudomonas stutzerii and Halomonas sp. Based on the characterization of colony morphology, the bacteria showed a big colony, appeared cream in color, and produced mucoid. Also, their cells were recognized as basil and Gram-negative.

\section{ACKNOWLEDGEMENTS}

The authors would like to thank you to the Bogor Agricultural University, Indonesia for the research support and the Ministry of Research, Technology and Higher Education for the research funding given.

\section{REFERENCES}

Babatsouli P, Fodelianakis S, et al. 2015. Single-stage treatment of saline wastewater with marine bacterial-microalgae consortia in a fixed-bed photobioreactor. J Hazard Mater. 292, 155-163.

Calderon K, Gonzalez MA, et al. 2013. Archaeal diversity in biofilm technologies applied to treat urban and industrial wastewater: recent advances and future prospects. Int J Mol Sci. 14 (9):18572-18598

Camargo JA, Alonso A. 2006. Ecological and toxicological effects of inorganic nitrogen pollution in aquatic ecosystems: A global assessment. Environ Int. 32: 831-849.

Constable M, Charlton MJF, et al.. 2003. An ecological risk assessment of ammonia in the aquatic environment. Hum Ecol Risk Assess 9:527548.

Diwan, Vaibrav D, et al. 2018. Does universal 16S rRNA gene amplicon sequencing of environmental communities provide an accurate description of nitrifying guilds?) J Microbiological Methods volume 151: 28-34.

Dong H, Zhang K, et al. 2017. Achievement, performance, and characteristics of microbial products in a partial nitrification sequencing batch reactor as a pretreatment for anaerobic ammonium oxidation. Chemosphere. Volume 183: 212-218.

Egamberdieva D, Davranov K, et al. 2018. Soil salinity and microbes: diversity, ecology and biotechnology potential. Extremophiles in
Eurasian Ecosystems: Ecology, Diversity, and Applications 8: $317-$ 332.

FAO. 2011. The State of Insecurity Food in The World. Food and Agricultural Organization, Rome.

FAO. 2016. The State of World Fisheries and Aquaculture. Food and Agricultural Organization, Rome.

Gao XY, Xu Y, et al. 2012. Bacterial diversity, community structure, and function associated with biofilm development in a biological aerated filter in a recirculating marine aquaculture system. Mar Biodivers. 42(1): 1-11

Guo Y, Zhou X, et al. 2013. Heterotrophic nitrification and aerobic denitrification by a novel Halomonas campisalis. Biotechnology Letters. 35. 12: 2045-2049.

Hadioetomo RS. 1983. Mikrobiologi Dasar dalam Praktek. Jakarta.

Hastuti YP, Rusmana I, et al. 2010. Profil tambak tradisional: tesktur tanah, total n-anorganik dan bakteri penghasilnya. J Akuakultur Indo 9: 119-126.

Hastuti YP. 2011. Nitrifikasi dan denitrifikasi di tambak. J Akuakultur Indo 10: 89-98.

Hastuti YP, Affandi R, et al. 2015. Optimum salinity for growth of mangrove crab Scylla serrata seed in recirculation systems. J Akuakultur Indo. 14: 50-57.

Hastuti YP, Nirmala K, et al. 2018. Protein profile and ammonia excretion of Mud Crab Scylla serrata with recirculation system. Pakistan J Biol Sci. 21 (6): 275-283.

Hastuti YP, Nirmala K, et al. 2018. Actual activity of nitrifying bacteria in culture of mud crab Scylla serrata under recirculating system with various light treatments. AACL Bioflux. 11 (5): 1476-1485.

Isnansetyo A, Getsu S, et al. 2014. Independent effects of temperature, salinity, ammonium concentration and $\mathrm{pH}$ on nitrification rate of the Ariake Seawater Above Mud Sediment. Hayati J Biosci 21: 21-30.

Kim JH, Guo X, et al. 2008. Comparison study of the effects of temperature and free ammonia concentration on nitrification and nitrate accumulation. Process Biochem 43: 154-160.

Marchesi JR, Sato T, et al. 1998. Design and evaluation of useful bacteria specific PCR primers that amplify genes coding for bacteria $16 \mathrm{~S}$ rRNA. Appl Environ Microbiol 64: 795-799.

Metaxa E, Deviller G, et al. 2006. High rate algal pond treatment for water reuse in a marine fish recirculation system: water purification and fish health. Aquaculture. 252:92-101

Miyahara M, Kim SW, et al. 2010. A potential of aerobic denitrification by Pseudomonas stutzeri TR2 to reduce nitrous oxide emissions from wastewater treatment plants. Appl Environ Microbiol 76: 46194625

Fitriyanto NA, Winarti A, et al. 2017. Identification and Growth Characters of Nitrifying Pseudomonas sp., LS3K isolated from odorous region of Poultry Farm. J Biol Sci 17 (1): 1-10

Richardson DJ. 2000. Bacterial respiration: a flexible process for a changing environment. Microbiol 146: 551-571.

Sambrook J, Russell. 2001. Molecular Cloning: A Laboratory Manual. 3rd ed. Cold Spring Harbor Laboratory Press, New York.

Sangnoi Y, Chankaew S, et al. 2017. Indigenous Halomonas spp. the potential nitrifying bacteria for saline ammonium wastewater treatment. Pakistan J Biological Sciences. 20:52-58

Stackebrandt E, Goodfellow M, eds. 1991.Nucleic acid techniques in bacterial systematics. Academic Press; Chichester, England.

Takenaka S, Zhou Q, et al. 2007. Isolation and characterization of thermotolerant bacterium utilizing ammonium and nitrate ions under aerobic conditions. Biotechnol Lett 29: 385-390.

Wang B, Gong Y, et al. 2017. Bacterial community structure in simultaneous nitrification-denitrification and organic matter removal process treating saline mustard tuber wastewater as revealed by $16 \mathrm{~S}$ rRNA sequencing. Bioresour Technol 228: 31-38.

White D. 2000. The Physiology and Biochemistry of Prokaryotes. Oxford University Press, Oxford.

$\mathrm{Xu}$ Y, Tengxia $\mathrm{H}$, et al. 2016. Nitrogen removal characteristics of Pseudomonas putida Y-9 capable of heterotrophic nitrification and aerobic denitrification at Low Temperature. BioMed Res Intl. 2017: 1429018. DOI: $10.1155 / 2017 / 1429018$

Zhang $\mathrm{J}, \mathrm{Wu} \mathrm{P}$, et al. 2011. Heterotrophic nitrification and aerobic denitrification by the bacterium Pseudomonas stutzeri YZN-001. Bioresour Technol 102: 9866-9869.

Zumft WG. 1997. Cell biology and molecular basic of denitrification. Microbiol Mol Biol Rev 61: 533-616. 